\title{
Biblioteket som rum i byens rum
}

\author{
Af Nan Dahlkild
}

\begin{abstract}
I artiklen undersøges det, hvorledes cendringer $i$ bibliotekernes karakter og opgaver afspejler sig $i$ deres rumlige udvikling og placering som rum i byens rum. Med udgangspunkt i teorier om bysociologi og offentlighedsformer undersøges sammenhoengen mellem bibliotekernes indre og ydre rum. Udviklingen fra samlinger med lukkede hylder til gradvis større åbenhed, flere aktiviteter og indtonkning $i$ byplanloegning og kulturpolitik dokumenteres og eksemplificeres. Konkret undersøges biblioteksrummets udvikling fra de første bygninger og projekter over bibliotekskatedraler og videnstempler til bredt kulturelt og socialt orienterede institutioner. Udviklingen sattes i forhold til både bibliotekernes funktioner og materialer fra samlinger til netvark, ligesom undersøgelsen inddrager betydningen af forskellige arkitektoniske retninger og udtryk. Bibliotekstyper og placeringer belyses ud fra såvel internationale som danske eksempler. Afslutningsvis perspektiveres eksemplerne på indtcenkning af biblioteker i byens rum med forslag til planlagning af selve biblioteksrummet som byrum.
\end{abstract}

Nan Dahlkild er lektor, ph.d. ved Det Informationsvidenskabelige Akademi, (nd@iva.dk)

\section{Indledning}

Bibliotekets rum kan sammenlignes med byens rum: En selvgroet eller planlagt struktur, der ordner utallige elementer og processer og gør dem overskuelige og tilgængelige. (Fig. 1 og 2) Ligesom biblioteksbygningen kan fortolkes som en bog, kan bibliotekets indre sammenlignes med en byplan. Bogen og reolen bruges ofte som arkitektonisk metafor. Som internationalt eksempel kan nævnes de fire hjørnetårne i Bibliothèque Nationale i Paris som udtryk for åbne bøger. I dansk sammenhæng har trækonstruktionerne i mødesalen i kvartershuset i Holmbladsgade på Amager form som reoler, og biblioteket på Rentemestervej i Københavns nordvestkvarter kan ses som en stabel af forskudte bøger.

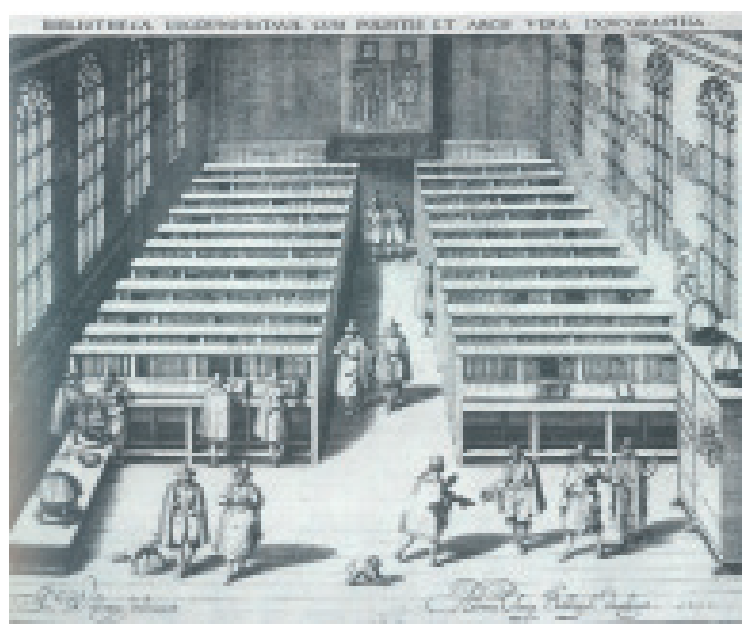

Figur 1. Biblioteket i Leiden 
Bibliotekets facade kan opfattes som bogens forside. Indgang og foyer kan læses som forord og indledning, skiltning som indholdsfortegnelse, reolerne som bogens linjer og bøgerne som bogstaver. (Thomas, 1996) Eller biblioteket kan læses som en byplan: Ekspeditionen som det centrale torv, afdelinger og emneområder som kvarterer, de enkelte reoler som huse og mellemrummene mellem dem som gader. (Linn, 2002; Dahlkild, 2007) Faktisk omtales mellemrummene mellem reolerne ofte som "gader". Ligesom byens kvarterer ændrer sig, og husene i byens gader skiftes ud og nybygges over tid, blandes gamle og nye bøger på reolerne.

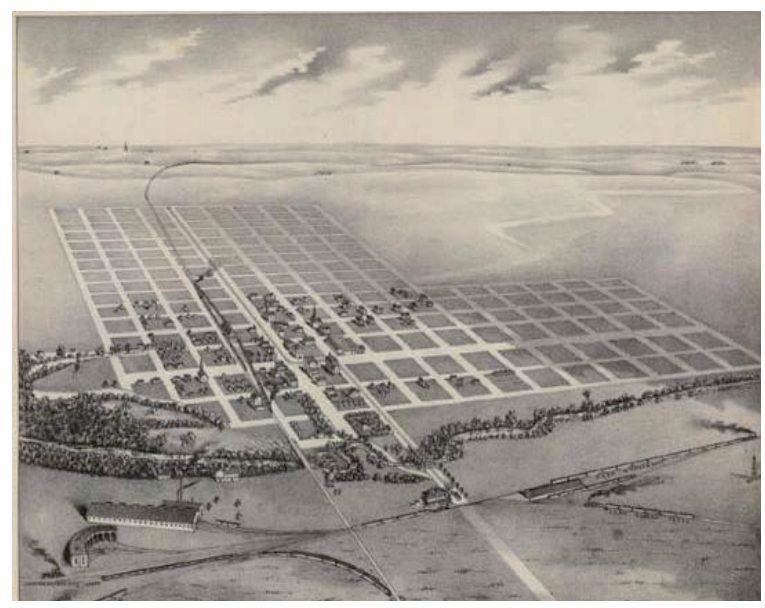

Figur 2. By i Midtvesten

Ligesom byerne og medierne udvikler sig, skabes der også nye biblioteksrum. Samfundsudviklingen og digitaliseringen omkring årtusindskiftet har haft afgørende betydning for ændringer af både byens og bibliotekets rum. Lineære byplaner og reolopstillinger er afløst af mere komplekse udformninger. Ligesom byerne er blevet grænseløse strukturer med fortætningspunkter, er bibliotekerne blevet dele af internationale informationsnetværk som "libraries without walls".

\section{Fra samling til netværk}

Det klassiske europæiske biblioteksrum med den oprindelige betydning "sted for opbevaring af bøger" var ikke tænkt ind i nogen byplanmæssig sammenhæng. Det var bygget op omkring sine egne materialer og præget af sin egen rumlige stabilitet og orden. Typisk var der stor identitet mellem samlingen og rummet. I barokbiblioteket var reolernes og bindenes størrelser og farver tilpasset hinanden.
Fra slutningen af det 18 . århundrede begyndte biblioteksbygninger at indgå i byplanlægningen, først $i$ tidens ideelle byplaner og senere i form af realiseringen af en række større byggerier. Udviklingen af store national- og forskningsbiblioteker førte til et markant biblioteksbyggeri, der ofte fik en central placering i forbindelse med byens parker eller pladser, og folkebibliotekerne fik karakter af åbne sociale rum, der havde betydning for demokratisering af læsning og viden. Omkring 1900 satte især de store amerikanske biblioteker det voksende udlån i system med avancerede transportsystemer fra indre transportbånd til mobile afdelinger med hestevogne og senere biler. Samtidig udvikledes et vidt forgrenet system af filialer, der fulgte med byudviklingen og de ekspanderende forstæder. De nye biblioteker integrerede sig i byens rum.

Indførelsen af åbne hylder hørte sammen udlånets stigende betydning og understregede yderligere åbningen af biblioteksrummet. Op gennem det 20 . århundrede voksede antallet af brugere, medier og aktiviteter. Et udvidet biblioteksbegreb pegede i retning af "kulturcentre" med nye aktiviteter og medier. Biblioteker og kulturcentre indgik i planlægningen af velfærdsbyens centerdannelser. (Bæk Pedersen, 2005)

I tiårene efter krigen forenedes folkebibliotekernes klassiske idealer om åbenhed og åbne hylder med den internationale modernismes forestillinger om åbne flydende rum, transparens og moduler i minimalistisk udformning. Bibliotekspolitisk var åbenheden yderligere forbundet med ønsker om fleksibilitet, en smidigere funktionsplan med friere muligheder for møblering og skiftende materialeopstillinger. Også de enkle indgange med glasdøre og de store glasarealer med både indblik og udblik signalerede åbenhed. De samme rationelle og lineære principper, som karakteriserede efterkrigstidens byplanlægning, gjorde sig gældende i biblioteksplanlægningen.

Med de elektroniske medier og senere digitaliseringen omkring årtusindskiftet ændrede både byer og biblioteker karakter. Digitaliseringens muligheder for at tilgængeliggøre store mængder af tekster, billeder og musik for en bruger, uanset hvor vedkommende måtte befinde sig, e-bogens potentialer for decentral lagring og læsning af litteratur og de sociale mediers nye debatformer er blevet en udfordring af det traditionelle fysiske biblioteks funktioner. Bibliotekerne 
fungerer i stigende grad som formidlere af et netværk af databaser, hvor de udnytter både digitaliseringens søgemuligheder og lagringsformer. Stadig flere tekster er både elektronisk søgbare og tilgængelige og dermed ikke længere stedsbundne. Slagordet "From collection to connection" formulerer denne udvikling og denne nye situation, der overordnet og generaliserende kan opstilles i skemaform:

Bibliotekernes indhold og aktiviteter:

\begin{tabular}{|l|l|}
\hline Frem til Renæssancen: & Samling \\
\hline Fra Oplysningstiden: & Samling + Udlån \\
\hline Fra det 19. og 20. århundrede: & Samling + Udlån + Aktiviteter \\
\hline $\begin{array}{l}\text { Fra slutningen af det 20. år- } \\
\text { hundrede: }\end{array}$ & $\begin{array}{l}\text { Samling + Udlån + Aktiviteter } \\
\text { + Digitalisering }\end{array}$ \\
\hline
\end{tabular}

Bibliotekerne er i årtusindskiftets medieparadigme blot et blandt utallige steder, hvor der kan hentes viden og kultur, ofte hurtigere og lettere end hvis man bevæger sig hen på biblioteket. Bibliotekernes funktioner forskyder sig derfor i retning af modellens højre side med større vægt på vejledning, læring og socialt nærvær.

I de følgende afsnit vil det blive undersøgt og eksemplificeret, hvorledes disse ændringer i bibliotekernes karakter og opgaver afspejler sig i deres rumlige udvikling og placering som rum $i$ byens rum. Med udgangspunkt i teorier om offentlighedsformer, bysociologi, biblioteksidentiteter og arkitektoniske udtryk forbindes bibliotekernes indre rum og funktioner med deres placering i det omgivende rum. Især undersøges sammenhængen mellem bibliotekernes åbning fra forholdsvis lukkede samlinger og rum uden sammenhæng med deres omgivelser til gradvis større åbenhed og indtænkning i byplanlægning og kulturpolitik. Med internationale og danske eksempler undersøges biblioteksrummets udvikling fra de første selvstændige biblioteksbygninger over de klassiske videnstempler til bredt kulturelt og socialt orienterede institutioner.

\section{Teorier om offentlighed, byrum og biblioteker}

Biblioteket som en del af det offentlige rum er i høj grad udgangspunkt for den engelske Comedia-gruppe, som bl.a. har beskæftiget sig med byplanlægning og urbane rum. De tre forfattere Liz Greenhalgh, Ken Worpole og Charles Landry undersøger i bogen Libraries in an world of cultural change (Green- halgh, Worpole \& Landry, 1995) ud fra en uafhængig position bibliotekernes udfordringer omkring årtusindskiftet. Deres udgangspunkt er forskellige betydninger af "offentlighed" som f.eks. mediernes "offentlighed" eller "offentlige sfære" med henvisning til Habermas eller byrummets "offentlige rum" med "offentlig adgang".

I indledningen sammenligner Comedia-gruppen parker og biblioteker som offentlige byrum med særlige kvaliteter som frirum: "But the study also "discovered", or identified, particular spaces and places - notably public libraries, parks and other more, locally specific civic cultures ... where it was still possible to note a liveliness, conviviality and sense of mutual respect ..." (Greenhalgh, Worpole \& Landry, 1995, s. vii) Ved sammenligningen med en offentlig park understreges bibliotekets betydning som frirum, men er samtidig lægges der mindre vægt på bibliotekernes traditionelle opgaver og samlinger.

Betydningen af biblioteket som offentligt rum understreges også senere i undersøgelsen, kombineret med kritik af byudviklingen: "As the vitality of streets and street cultures has been killed by cars, as shopping streets have become displaced by private covered malls, as museums and other free venues have been forced to impose entrance charges, so the opportunities to wander, to browse, to stand and chat, to sit and watch the world go by become squeezed and constrained. This, we feel, is one of the pre-eminent values of the public library, as neutral space, as democratic, non-sectarian territory." (Greenhalgh, Worpole \& Landry, 1995, s. 12) Biblioteket er her blevet et frirum for en truet livsverden, og dette forhold rykkes frem blandt bibliotekets vigtigste værdier. I denne betydning er bibliotekerne offentlige rum i samme bysociologiske forstand som den italienske kartograf Giambattista Nollis kort over Rom fra 1748, som forlænger gadens offentlighed ind i offentlige bygninger.

Undersøgelsen handler dog også om bibliotekets identitet eller "libraryness" og dermed om, hvad der gør biblioteket til et særligt sted. Som vigtige punkter nævnes bibliotekets uafhængige, demokratiske og "værdifrie" karakter, "the right to know" i form af respekten for borgerrettigheder, biblioteket som vindue mod verden samt biblioteket som "sanctuary" i form et "fredhelligt sted" eller "frirum". Til bibliotekets historiske identitet hører også reglen om tavshed el- 
ler i nutiden "a quiet haven in a sea of urban noise". (Greenhalgh, Worpole \& Landry, 1995, s. 51) Endelig indgår biblioteksbygningens udformning som en særlig kvalitet: "Modern buildings and bright interiors continue to reflect ideas of intellectual rights, the centrality of education in our society and the role of public libraries in helping to sustain a public realm." (Greenhalgh, Worpole \& Landry, 1995, s. 53)

Også begrebet "det tredje sted" handler om behovet for uformelle mødesteder og sociale frirum. Begrebet er i de seneste år slået igennem i forbindelse med diskussioner om bl.a. folkebibliotekernes fremtid, selv om det ikke i udgangspunktet handler om biblioteker. Begrebet er oprindelig udformet af den amerikanske sociolog Ray Oldenburg i bogen The Great Good Place fra 1989. Her er "det tredje sted" defineret som et uformelt mødested mellem "det første sted" hjemmet og "det andet sted" arbejdet. Dette tredje sted kan være ramme om samvær, samtaler og diskussioner, som ikke er styrede eller målrettede. De defineres som "the core settings of informal public life". (Oldenburg, 1989, s. 16) Som det understreges af undertitlen Cafés, Coffee Shops, Bookstores, Bars, Hair Salons and other Hangouts at the Heart of a Community, er der tale om uformelle mødesteder som kaffehuse, cafeer, tavernaer, boghandeler og barer, hvor man uforpligtende kan hænge ud mellem hjem og arbejde. Bogen er senere fulgt op af Celebrating the Third Place fra 2001, som er en antologi med eksempler på "tredje steder" (Oldenburg, 2001). Begrebet har bl.a. inspireret indretningen af en boghandel i Michigan, som med sine mange uformelle aktiviteter har som mål at være lokalsamfundets dagligstue.

Bogen og begrebet er udformet som en kritik af uddøende amerikanske bycentre og et isoleret forstadsliv, domineret af privatbilisme og storcentre. Her savnes lokal forankring, tætte sociale relationer og offentlige rum. Det er Oldenburgs mål at imødegå dette tab af uformelle offentlige rum ved at synliggøre, styrke og udvikle "tredje steder", som stadig eksisterer, eller som kan skabes, ikke blot som rekreative områder, men også som vigtige forudsætninger for demokratiet.

Det er dog ikke alle offentlige rum, der falder ind under betegnelsen "det tredje sted". Oldenburg opstiller i alt otte definitioner, som lægger vægt på at:
1. Der er tale om et neutralt sted.

2. Stedet er inkluderende i forhold til sine brugere, som

3. mødes på samme vilkår som i de historiske kaffehuse, hvor samtale er hovedaktivitet.

4. Stedet er åbent og tilgængeligt.

5. Der er stamgæster.

6. Det er et "enkelt" sted.

7. Der er "samspil" mellem gæsterne, og

8. stedet har kvaliteter som "et hjem uden for hjemmet".

Selvom "det tredje sted" ofte bruges som forbillede for biblioteksudvikling, fremgår det af Oldenburgs definitioner, at begrebet er møntet på lokalsamfundets mange varianter af uformelle mødesteder. Faktisk skriver Oldenburg, at f.eks. biblioteker og hospitaler ikke lever op til "det tredje steds" enkle og uformelle organisering: "Unlike hospitals or libraries, which have exacting, complicated, and expensive internal requirements, third places are typically modest, inexpensive, and modest by comparison." (Oldenburg, 1989, s. 203.) Definitionerne svarer dog i varierende grad til forskellige bibliotekstyper, f.eks. i forbindelse med lige vilkår, tilgængelighed, åbenhed og betydning for demokratiet.

Når begrebet "det tredje sted" har vundet indpas i biblioteksdebatten, hænger det utvivlsomt sammen med diskussionen om bibliotekernes fremtidige rolle og nytænkningen af deres funktioner. Netop for bibliotekerne er det vigtigt at være forankret i lokalsamfundet, og Oldenburgs understregning af de åbne og uformelle mødesteders betydning for lokale netværk og for demokratiets samtale $\mathrm{i}$ bred forstand ligger i forlængelse af traditionelle biblioteksværdier.

Der er mange ligheder mellem Oldenburgs begreber og Habermas' teorier om livsverden og offentlighed, ikke mindst det fælles omdrejningspunkt i form af de engelske kaffehuse som et historisk eksempel på samtalesituationer og konstruktionen af en ideel borgerlig offentlighed. Netop samtalen som hovedaktivitet er et af Oldenburgs centrale principper for definitionen af "det tredje sted" og kan sammenlignes med det tidlige 1700-tals konversationskultur, som har direkte forbindelse til udviklingen af tidens aviser og tidsskrifter og mere filosofisk til samtalen og dialogen, der hos Habermas får dybere betydning med den "herredømmefrie" dialog som ideal. 
En række arkitekturteorier fra tresserne og fremefter har ligeledes forholdt sig kritisk til tabet af identitet og offentlighed i byens rum. Kritikken er ikke uden lighed med teorierne om forholdet mellem system og livsverden. Det gælder f.eks. Kevin Lynch' The Image of the City fra 1960 (Lynch, 1960) om orientering og bevægelse i byrummet og Gordon Cullens The Concise Townscape fra 1961 (Cullen, 1961) med blik for betydningsbærende detaljer. Lynch' visuelle bysociologi tager udgangspunkt $\mathrm{i}$ behovet for at orientere sig i storbyen ved at identificere og skabe kendemærker, på samme måde som eskimoer eller indianere finder vej i naturlige omgivelser. Han udvikler et begrebsapparat, der dels overordnet beskæftiger sig med byens identitet, struktur og mening, dels kan bruges som en metode til at undersøge vigtige elementer i byens rum. Lynch' begreber er "paths", "edges", "districts", "nodes" og "landmarks", der betegner bevægelsesmønstre, grænser mellem områder og trafikknudepunkter eller centrale pladser. Særlig interessant i denne sammenhæng er begrebet "landmarks" eller på dansk "pejlemærker" eller "vartegn", der bruges som fælles orienteringspunkter i byen.

Flere af disse undersøgelser kan forbindes med begrebet "stedets ånd" eller på latin "genius loci". Begrebets oprindelige betydning kan føres tilbage til antikkens mytologi i form af lokale beskyttende guder eller ånder. I nutidig sammenhæng betegner det $\mathrm{i}$ bredere sammenhæng geografi, klima, historisk baggrund og atmosfære i et bestemt område eller region. Inden for arkitektur, havearkitektur og landskabsplanlægning har begrebet haft betydning for nye anlæg eller byggerier, der tilpasser sig stedets karakter, økologi og klima. Inden for arkitekturteori kan "stedets ånd" have mere eksistentiel filosofisk og fænomenologisk betydning, men det kan samtidig anvendes som ramme for forståelse og fortolkning af særlige historiske og sociale baggrunde og omstændigheder.

Begrebet er blevet udforsket og anvendt af den norske arkitekturhistoriker og -teoretiker Christian Norberg-Schulz. I sin bog Genius Loci. Towards a Phenomenology of Architecture (Norberg-Schulz, 1980) undersøger han karakteristiske naturlige eller menneskeskabte steder med eksempler fra landskaber, byer og bygninger i Skandinavien, Europa og Afrika. Norberg-Schulz interesserer sig for begrebets dybere betydning i forbindelse med basale og eksistentielle livssammenhænge i et område eller en region. Han er inspireret af Heideggers fænomenologiske filosofi, hvor "stedet" opstår med bosætningen. Begrebet kan anvendes i forbindelse med forståelse og placering af lokale kulturelle institutioner.

I Danmark har arkitekten Jan Gehl og samarbejdspartnere undersøgt lovmæssigheder omkring ophold og bevægelsesmønstre i byens rum og den kulturelle, sociale og æstetiske betydning af indretning og møblering af byens gader og pladser. Undersøgelserne er formidlet i tekst og billeder i udgivelser som Livet mellem husene (Gehl, 1971) og Nye byrum (Gehl \& Gemzøe, 2000). Undersøgelserne af muligheder for ophold og samvær kan overføres på f.eks. biblioteker som indre byrum, f.eks. attraktive placeringer af siddepladser og inviterende rum eller afvisende mure og tomme pladser.

Omkring årtusindskiftet er udviklingen af byrum i bredere forstand blevet forbundet med byfornyelse af nedslidte områder, regional udvikling og incitamenter for økonomisk udvikling. Flere store kulturelle byggerier i form af biblioteker og museer har været forbundet med Bilbao-effekten som oplevelsesøkonomisk tænkning, opkaldt efter Guggenheim Museet i Bilbao og dets betydning som arkitektonisk ikon for omdannelsen af en nedslidt industriregion til et attraktivt område for turisme. Arkitekturteoretikeren Charles Jencks har i sin bog The Iconic Building. The Power of Enigma beskæftiget sig både med Bilbaoeffekten og den særlige type af arkitektoniske ikoner, som er forbundet med internationale stjernearkitekter, deres fremtræden i medierne og mediernes betydning for promoveringen af deres arkitektur: "But it was the implications of the "Bilbao Effect" that were obvious to the media, and to every aspiring metropolis. If a city can get the right architect and the right creative moment in his or her career, and take the economic and cultural risk, it can make double the initial investment in about three years. It can also change the fortunes for a declining industrial region. To put it crudely, the tertiary economy of the culture industry is a way out of Modernist decline: Post-modernize or sink!" (Jencks, 2005, s. 19)

Nyere bysociologi beskæftiger sig bl.a. med byens forandringer fra overskuelige og planlagte enheder til grænseløse strukturer med nye hastigheder og virkelighedsformer, der udvides af elektroniske billedmuligheder og digitale netværk. Den lineært planlagte by afløses af skiftende knudepunkter i form 
af "rhizomer". Biograflærredet og skærmen dematerialiserer arkitekturen og byens karakter, og farten og bilismen ændrer livsformer og bevægelsesmønstre. Byen opleves med bilistens blik. Hos William J. Mitchell er "stedets ånd" erstattet af betydningen af den digitale kode. Hans pointe i bogen e-topia er dog, at også i nye digitalt baserede bysamfund vil stedet have betydning. I kapitlet "The Persistent Power of Place" diskuterer han betydningen af steder, hvor man kan mødes ansigt til ansigt, hvor genbrugsbutikker har særlige varer, og hvor boghandeler indretter sig med attraktive cafeer: "They will emphasize the unusual, the elsewhere unobtainable, and the things that cannot (at least yet) be pumped through a wire." (Mitchell, 1999, s. 142)

I forlængelse af disse forskellige teorier om offentlighedens og stedets betydning kan man undersøge, om selve biblioteksbygningen som sted er en særlig bygningstype med særlige kvaliteter? Ligesom den engelske Comedia-gruppe har nærmet sig en definition af begrebet "libraryness", kan man undersøge, om biblioteksbygninger har en særlig identitet, placering, fremtræden og udformning.

\section{Fra sakrale bygninger i en metropol til havebyer med kulturelle centre}

Den første egentlige biblioteksteoretiker Gabriel Naudé besæftigede sig i sit skrift Vejledning $i$ biblioteksarbejde fra 1627 især med selve samlingen og dens sammensætning og ordning. Selv om bibliotekets endemål for Naudé var adgang for offentligheden, forestillede han sig ikke nogen selvstændig biblioteksbygning. Han gik ind for en hensigtsmæssig og praktisk indretning af bibliotekslokalet i modsætning til mange af tidens pragtbiblioteker. Med hensyn til beliggenheden foretrak han "... den del af huset, som ligger fjernest fra støj og larm ... og i stedet anbringe biblioteket om muligt mellem en rummelig gård og en smuk have, hvor det kan få lyset frit ind og kan give læseren en behagelig og uhindret udsigt ..." (Naudé, 1970, s. 100)

I oplysningstiden opstod der flere store visioner om kulturelle byggerier. Især i Frankrig fik oplysningsideerne et markant arkitektonisk udtryk hos en gruppe af "oplysningsarkitekter" eller "revolutionsarkitekter", hvis projekter og byggerier både repræsenterede et radikalt nyt formsprog med nøgtern brug af enkle geometriske former og samtidig var forsøg på at skabe ideelle sociale rammer om et nyt oplyst samfund. Arkitektur, byplaner og indretning var som "talende arkitektur" en del af oplysningsprojektet. Den franske revolutionsarkitekt Étienne-Louis Boullée forestillede sig en serie af aldrig opførte projekter til "sakrale bygninger til en metropol" som manifestationer af videnskabens og oplysningens betydning. Hans uhyre professionelt tegnede og geometrisk forenklede planer omfattede bl.a. et monument for Isaac Newton, et tempel for fornuften, et museum, et stort nationalt bibliotek m.fl.

I denne sammenhæng er især Boullées store biblioteksutopi i form af flere forslag til Det kongelige Bibliotek i Paris fra 1785 interessant. Biblioteksprojektet var gigantisk, præget af symmetri, nøgne vægge og boggallerier. Boulées gigantiske udkast til operaer, museer og biblioteker er ligesom den store franske encyklopædi en del af oplysningens "store fortælling”. På samme måde som encyklopædien skulle biblioteket indsamle, ordne og formidle al tilgængelig viden, som var forudsætning for en oplyst og kritisk diskurs. Boullées bibliotek kan ses som en arkitektonisk vision af encyklopædien, diskursen og den oplyste offentlighed.

Oplysningsarkitekturen var ikke noget entydigt fænomen. Den afspejlede tidens modsætninger mellem fornuft og følelse, mellem teknik og natur, mellem en saglig, rationel og monumental arkitektur på den ene side og på den anden side antikke ruiner, små fantasifulde hytter og enkle lysthuse i romantiske haver. Et fint eksempel er forfatterinden Betje Wolffs lille stråtækte løvhyttebibliotek på godset Lommerlust i Beverwijk i Holland fra 1780. (Fröberg, 1998, s. 143-149) Biblioteket var samtidig Betje Wolffs arbejdsværelse, hvor hun skrev sine i samtiden populære brevromaner. Hvor Boullées vision var en del af oplysningens store samfundsforandrende projekt, repræsenterede Betje Wolffs lysthusbibliotek den nære livsverden, følelsen, fordybelsen og refleksionen.

I øvrigt kunne de snoede stisystemer i de første romantiske haver i sig selv minde om encyklopædiske vandringer mellem visdomsord, symboler, stilarter og verdensdele. Der opstod "lærdomslandskaber" som i Wörlitz ved Dessau med søer, kanaler, frugthaver, monumenter, templer og et bibliotek med have- og jordbrugsvidenskabelig litteratur. Parken var offentligt tilgængelig, og indbyggerne kunne frit 
tage den opbyggelige litteratur med sig på vandringer i området. (Estvad Petersen, 2000, s. 134-135)

Selv om Boullées projekter forblev på papiret ligesom de allerfleste af revolutionsarkitekturens fantasier, kom de til at påvirke klassicismens og historicismens kulturelle byggeri. Det nittende og det tyvende århundredes biblioteker, museer og operaer fik en langt mere central placering i bybilledet, og de store hvælv og kupler realiseredes i midten af det 19. århundrede i et hidtil uset format $i$ form af industriarkitekturens nye konstruktioner, f.eks. Henri Labroustes Bibliothèque St. Geneviève i Paris fra 1850 og Universitetsbiblioteket i København fra 1861, tegnet af Johan Daniel Herholdt. En monumental og pompøs bibliotekstype i forskellige historiske stilarter gik igen i de store nationalbiblioteker og universitetsbiblioteker, der frem til 1. Verdenskrig opførtes i hovedstæder og storbyer i Europa, i Nord- og Sydamerika og i de store europæiske imperier.

Boston Public Library opførtes 1887-95 som "folkepalads" af arkitekterne McKim, Mead \& White med central beliggenhed ud til Copley Square. Den markante facade hentede inspiration fra Bibliothèque St. Geneviève. Bygningens fire fløje dannede et kvadratisk gårdrum, som svarede Naudés forestillinger om en bibliotekshave, afskærmet fra byens larm. Den grønne gård med springvand lå som en fredfyldt og klosteragtig forlængelse af læsesalen og blev meget søgt. Flere af de store amerikanske folkebiblioteker var en del af byudviklingen med deres mange filialer og mobile betjeningssystemer.

I Danmark blev Universitetsbibliotekets nye bygning fra 1861 en del af universitetsfirkanten ved Frue Plads som centrum for Københavns latinerkvarter. Den lange facade med inspiration fra kirkearkitekturen vendte dog ikke ud mod selve pladsen, men ud mod gaderummet i Fiolstræde. I Århus indgik Statsbibliotekets første bygning i et ambitiøst forslag om en samlet institutionsbebyggelse på Bispetoften. Dette monumentalt tænkte projekt skulle omfatte både parker, et teater, som vendte ind mod byen, et bibliotek med facade ud mod åen, en latinskole med facade mod Vester Alle og mulighed for en universitetsafdeling. Det færdigbyggede bibliotek fra 1902, tegnet af Hack Kampmann, kom senere til at indgå i et anlæg, hvor det lå over folkebiblioteket i Mølleparken. Det Kongelige Bibliotek, der fra 1673 havde været en del af Kunstkammerbygningen på Slotsholmen, flyttede i 1906 til en ny katedralagtig bygning på den anden side af Bibliotekshaven, som gav biblioteket en tilbagetrukken placering i forhold til de øvrige bydele. Flere andre placeringer havde dog været under overvejelse, både på Slotsholmen og i forbindelse med anlægget af det københavnske Voldgadekompleks, bl.a. en beliggenhed ud for Studiestræde eller mellem Frederiksholms Kanal og den daværende Vester Voldgade.

I sin bog To-Morrow: A Peaceful Path to Real Reform fra 1898 argumenterede Ebenezer Howard for en ny type af selvforsynende havebyer omkring de store industrielle storbyer. Disse byer skulle være af overskuelig størrelse, og de skulle omgives af grønne bælter af dyrket land. Også i byernes centre skulle der ligge grønne parker, og omkring det grønne indre skulle der ligge en ring af offentlige institutioner i form af rådhus, koncertsal, teater, bibliotek, museum, galleri og hospital. Howards ideer fik stor betydning for udvikling af forstæder og havebyer, selv om ikke alle ideer blev realiseret.

Howards forestillinger svarede fint til den lille mønsterby med mønsterbibliotek, som blev opført i forbindelse med Landsudstillingen i Århus i 1909. Denne lille idealby kom til at bestå af små 15 huse omkring en hovedgade, som mundede ud i pladsen foran stationsbygningen. Et af husene var en fælles biblioteks- og forsamlingsbygning, som med det lille foranliggende haveanlæg fik en fin placering på stationsbyens hovedgade. Den blev udformet som en vinkelbygning, hvor biblioteket havde til huse i den lille fløj, mens forsamlingssalene lå i hovedfløjen, næsten som en tolænget gård. Placeringen på grunden gav mulighed for en lille åben have med bænke. Indgangene var landligt enkle uden monumentalitet. Den store forsamlingssal kunne rumme ca. 500 mennesker og den mindre sal ca. 200. Det lyse biblioteksrum var møbleret med borde, stole og reoler af fyrretræ og holdt i gule, grønne og brune farver. Der var åbne hylder. Biblioteket var tænkt ind i byplanen. Hovedgaden, bibliotekshaven og selve biblioteksrummet lå i forlængelse af hinanden. (Dahlkild, 2011, s.16-121)

Stationsbyudstillingens "kulturcentrum" videreførtes af flere nye og større projekter i mellemkrigstiden i form af folkegårde, forsamlingsgårde og samfundscentre. De forskellige projekter rettede sig mod fritiden som moderne socialt fænomen og var 
ikke kun tænkt placeret i mindre byer, men også som kvartercentre med sociale opgaver i storbyerne.

\section{Videnstempler, sommerfugleplaner og monumen- tal beliggenhed}

Mens der omkring år 1900 var stor forskel på de store statslige bibliotekskatedraler med central placering og folkebogsamlingernes mere ydmyge lokaler i sidegaderne, fik også byggeriet af folkebiblioteker i mellemkrigstiden en mere fremtrædende plads i bybilledet, svarende til ambitionerne hos tidens ledende biblioteksfolk. De nye folkebiblioteker fik ofte en ophøjet placering med tempelagtig indgang og facade. Samtidig fik de i det indre en klar funktionsopdeling i form af "sommerfugleplanen" med voksenudlånet som det midterste og største rum, til højre herfor voksenlæsesalen og til venstre børneafdelingen. Planen afspejlede periodens tendenser i retning af arbejdsdeling og professionalisering af bibliotekernes opgaver. Et karakteristisk eksempel er hovedbiblioteket på Frederiksberg fra 1935 med ophøjet beliggenhed, gennemført ydre og indre symmetri, funktionsopdeling og børnebiblioteket som en formindsket udgave af voksenbiblioteket. I mange år var biblioteket forbillede for nyt biblioteksbyggeri.

Daværende biblioteksdirektør Thomas Døssing formulerede selv sit syn på indretningen af "det moderne folkebibliotek" i en agiterende udgivelse om Folkebibliotekerne før og $n u$ fra 1924. Her understregede han tilgængelighed i form af egen bygning på byens hovedgade og en reguleret tredelt indretning: "Hvad er da et moderne Folkebibliotek? ... Det ligger som flere af de nye Biblioteker på en Hovedgade i sin egen Bygning ... Biblioteket er altså praktisk taget tilgængeligt naarsomhelst og for hvemsomhelst. Gennem en rummelig Forstue kommer vi ad Døren til højre ind i Udlaanslokalet. Færdslen er reguleret: Indgang ad en Dør og Udgang ad en anden ... Udlaanslokalet er et stort langstrakt Rum midt i Bygningen. Til højre findes Læsesalen for Voksne og til venstre Læsesalen for Børn ..." (Døssing, 1924, s. 9-13.)

Ikke alle biblioteker blev dog opført med attraktiv adresse på hovedgaden. I sin anmeldelse af Thisted Bibliotek fra 1938 beklagede Bogens Verdens anmelder Robert L. Hansen den afsides beliggenhed i udkanten af byen. Oprindelig skulle biblioteket have ligget ved torvet, men måtte vige for en parkerings- plads. Derfor måtte byggeriet flytte fra denne "smukke Plads i Solen" til en mindre central placering i et villakvarter: "Et Folkebibliotek kan ligge nok saa smukt "i Byens rolige, smukkeste Kvarter", det faar aldrig den Chance for at virke paa Manden fra Gaden, som naar det ligger, hvor denne Mand færdes ...” (Hansen, 1938, s. 167)

Typisk rykkede folkebibliotekerne dog fra sidegadernes hjemlige læsestuer frem til større og mere selvstændige bygninger om end ikke ved hovedgaden, så dog med en mere central beliggenhed eller med mere plads på større grunde i byernes udkanter. Især de nye biblioteker i Århus fra 1934 og i Nyborg fra 1939 fik en central placering. I Århus var biblioteket tænkt ind i byplanen som en del af anlægget omkring Mølleparken, hvor biblioteket kom til at ligge som indramning af parken. Anlæggets hovedakse fortsatte fra parken gennem bibliotekets hovedindgang $\mathrm{i}$ ind $\mathrm{i}$ voksenudlånet. Også i Nyborg var der sammenhæng mellem ude og inde. Placering og grundplan havde dog en friere og mere åben udformning. Fra bibliotekets lave glasloggia kunne man færdes i alle retninger, både i bibliotekets frit placerede rum og i parken udenfor.

Flere af mellemkrigstidens store skandinaviske videnstempler fik en næsten Akropolis-lignende placering i bybilledet. Det gjaldt f.eks. Stadsbiblioteket i Stockholm fra 1928 og Det Deichmanske Bibliotek i Oslo fra 1933. I Oslo gav de mange trapper op til biblioteket med den ophøjede beliggenhed anledning til en satirisk tegning. (Fig. 3)

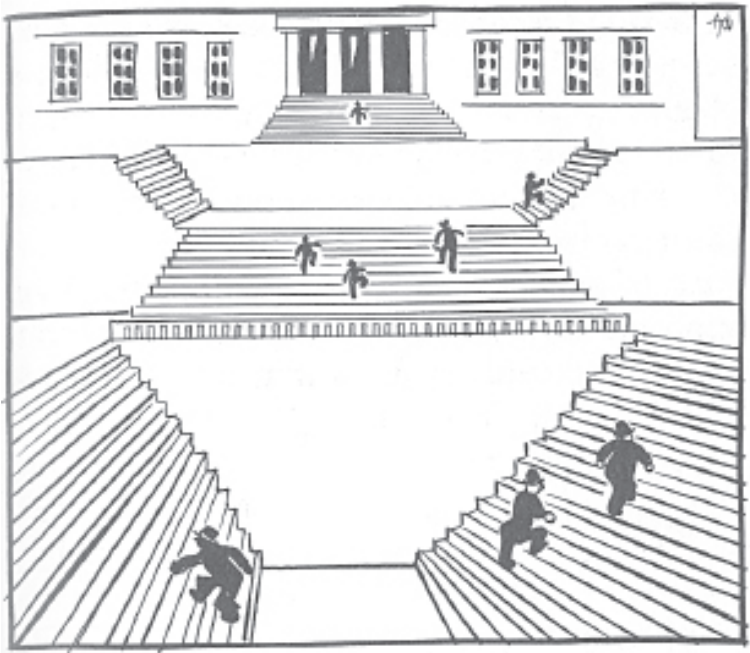

Figur 3. Tegning af trapper op til Det Deichmanske Bibliotek i Oslo 


\section{Modernismens rationelle, lineære og fleksible rum}

Biblioteksbyggeriet $\mathrm{i}$ efterkrigstiden var både internationalt og i Danmark præget af modernismen. Det gjaldt både konstruktion og rumopfattelse. Mens ambitionen i mellemkrigstiden var videnstemplet på hovedgaden med en fast ruminddeling, som fulgte sommerfugleplanen, skiftede idealerne i efterkrigstiden til det lave, åbne bibliotek med fri beliggenhed, som i det indre bestod af et stort åbent rum med serielle, men i princippet fleksible reolopstillinger. Som der stod i beskrivelse i Folkebiblioteker i Danmark fra 1967: "Pludselig ligger det nye bibliotek der, bredt, lavt og fladt, som havde det på een nat hævet sig op af græsplænen”. (Drehn-Knudsen, 1967, s. 94)

Lige efter krigen var Bispebjerg Projektet i det nordvestlige København eksempel på en fortsættelse og modernisering af mellemkrigstidens folkegårde og samfundscentre. Som forstadskvarter var området planlagt med gode og sunde boliger i grønne områder, men uden muligheder for sociale og kulturelle aktiviteter i fritiden. Projektet, der blev udformet af arkitekten Edvard Heiberg, omfattede forsamlingssal og friluftsscene, bibliotek, gymnastiksal, selskabslokaler samt en lang række lokaler til fritidsaktiviteter. På planen var det omgivet af grønne plæner og passede dermed ind i områdets øvrige byplanlægning, der var præget af funktionalismens idealer om lys og luft.

Projektet og tankerne bag det var forudseende. Som vision pegede det frem mod tressernes kulturcentre, og det repræsenterede en sociologisk orienteret indtænkning af kulturen i byplanlægningen. Heiberg understregede forbindelsen til forsamlingstraditionen på landet, men forbandt samtidig projektet med det moderne storbyliv og fik inspiration fra både de engelske New Towns, de svenske forstadscentre og funktionalismen fra Bauhaus. (Dahlkild, 2011, s.196198)

Hørsholm bibliotek fra 1956, tegnet af Jørgen Juul Møller og Holger Næsted, lå i et grønt område i udkanten af forstaden nord for København. Som det første åbne etrumsbibliotek repræsenterede det efterkrigstidens store nybrud i dansk biblioteksbyggeri som et både arkitektonisk og indretningsmæssigt paradigmeskift. Her brød den internationale modernisme igennem med fleksibilitet, moduler og transparens i minimalistisk udformning. Folkebibliotekernes klassiske idealer om åbenhed og åbne hylder forenedes her med den internationale modernismes forestillinger om det åbne flydende rum og slagordet "Less is more". Bibliotekspolitisk var åbenheden forbundet med ønsker om fleksibilitet, en smidigere funktionsplan med friere muligheder for møblering, monteringsmønstre og skiftende materialeopstillinger. Det lukkede institutionspræg skulle vige for "individuelle, æstetisk betonede trivselsinteriører." (Plovgaard, 1967, s. 103)

I Bogens Verden gav Sven Plovgaard da også sin omtale titlen "Nye signaler for biblioteksbyggeriet" og skrev: "Med den nye biblioteksbygning i Hørsholm ... står den danske biblioteksverden overfor en virkelig nyskabelse, både hvad angår det bygningstekniske, det æstetiske og det biblioteksmæssige. I ganske sjælden grad er disse tre områder her smeltet sammen om en bærende idé: det flexible hus, huset med eet stort rum, som kan opdeles alene efter inventaropstillingen efter skiftende behov og uden bygningsmæssige ændringer." (Plovgaard, 1957, s. 81-87)

Den lette og behagelige møblering kunne aflæses som udtryk for mere serviceorienterede formidlingsformer end tredivernes markante folkeoplysningsstrategi, svarende til 1964-lovens ændring af formålsparagraffen om folkebibliotekernes kulturformidling fra "virke for" til "stille til rådighed". Samtidig gav de modernistiske facader bibliotekerne en mere anonym fremtræden i bybilledet. Mens bibliotekskatedralerne fra omkring 1900 og mellemkrigstidens videnstempler markerede sig med indgangspartier med høje trapper og indre rum med højt til loftet, havde de modernistiske biblioteker enkle indgange og lave, horisontalt orienterede rum. De havde som mål at kombinere tilgængelighed af samlingerne med attraktive og åbne opholdsrum.

I tresserne blev forestillinger om kulturcentre en vigtig del af periodens kulturdebat og velfærdssamfundets kulturpolitik. I forhold til de foregående årtiers projekter blev vægten i højere grad lagt på kreative og kunstneriske aktiviteter under påvirkning af modernismens kunstopfattelse. Det blev diskuteret, om bibliotekerne med formuleringerne om kulturelle aktiviteter og nye medier i 1964-loven skulle være de nye kulturcentre, eller om de skulle være en blandt flere former for nye kulturelle centre. Under alle omstændigheder gav loven bibliotekerne mulighed for 
at tage initiativ til kulturelle aktiviteter og fungere som kulturcentre med nye medier og aktivitetsområder, som også afspejlede sig i den rumlige indretning. Kulturcentre blev en del af planlægningen af velfærdsbyen. (Bæk Pedersen, 2005)

Stadsbiblioteket i Lyngby blev opført 1964-68 og lå i forlængelse af periodens kulturpolitiske visioner. Adgangen til biblioteket sker fra Lyngby Hovedgade, og biblioteket forbinder dermed ligesom Nyborg Bibliotek det centrale bymiljø med den omgivende natur, idet man på få øjeblikke kan bevæge sig fra den trafikerede hovedgade ind til bibliotekets centrale rum med transparente glasfacader med udsigt ud til Lyngby Sø. Ligesom kunstmuseet Louisiana inddrog byggeriet et tidligere landsted til moderne kulturelle formål. Der var bibliotekscafé og udstillingsarealer, og der blev inddraget nye medier som kunst og musik. I det indre var biblioteket fleksibelt og transparent med det store åbne rum med mange funktioner og med det svævende galleri med udsigt til søen gennem den store glasfacade. Børnebiblioteket blev udformet som et kreativt legelandskab af Nanna Ditzel. Den luftige café var møbleret med hvide tulipanstole og tilhørende borde, tegnet af Eero Saarinen. Ligesom bibliotekets stil i øvrigt signalerede cafeen lethed og modernitet. Den vendte med sine store vinduesarealer ud til den omkransende plads med et skulpturlandskab af Willy Ørskov.

Tilsvarende forestillinger kom til udtryk ved anlægget af Rødovre Hovedbibliotek, tegnet af Arne Jacobsen og indviet i 1970. Byggeriet afspejlede Rødovres vækst som forstad og velstandsstigningen i tiårene efter krigen. Det var en del af en større plan, der også i forskellige variationer omfattede rådhus, rådhusplads, bibliotek og boligblok. Anlægget omkring rådhus og bibliotek var udtryk for modernismens byplanidealer i form af åbne, grønne byområder med forskellige funktionsbestemmelser. Den flisebelagte rådhusplads udgjorde planens urbane rum.

I modsætning til det transparente stadsbibliotek i Lyngby er biblioteket i Rødovre omgivet af en mur uden vinduer med to indgange $i$ hver sin side som eneste åbninger. Bygningen kan læses som en lukket bog, som åbner sig, når man bevæger sig ind i den. Går man ind i biblioteket fra den flisebelagte plads, er der ikke nogen niveauforskelle eller trapper. Det indre er opdelt af forskellige funktionsområder. Fra forhallens skrankeområde med udlån og aflevering går man til venstre ind i børneafdelingen og til højre ind i voksenafdelingen. Fortsætter man ligeud, kommer man ind i den store sal, som blev defineret som foredragssal, men med mange funktioner. Den kan bruges til både udstillinger, mindre koncerter, teater, foredrag og debat. Den centrale placering af salen markerede bibliotekets betydning som kulturcenter.

Den ydre retvinklede orden gik igen i den indre orden, både rumligt og møbleringsmæssigt. Voksenudlånets serielle opstilling af parallelle reoler med samme afstand og højde svarede til modernismens rationelle idealer for både indretning, byggeri og byplanlægning. Byplanens rette linjer og serielle karakter fortsatte ind i udlånssalen. Rækken af ensartede reoler kunne visuelt sammenlignes med Le Corbusiers eller Ludwig Hilbesheimers højhusprojekter. Samtidig svarede den rationelle og næsten magasinagtige reolopstilling til den universelle orden i bibliotekernes fortløbende decimalklassedeling. Voksenlæsesalen og børnebiblioteket var møbleret med tilsvarende orden, for børnebibliotekets vedkommende dog med små udgaver af Arne Jacobsens møbler. Et særligt legelandskab var karakteristisk for periodens møbleringsmæssige eksperimenter og unddrog sig den serielle orden.

Gårdhaverne giver fine udsigter fra både publikumsrum og kontorer. De enkelte gårdhaver er forskelligt beplantede med roser, taks, elefantgræs og forskellige mindre træer og blomstrende buske. De ligger i forlængelse af traditionen for bibliotekshaver, som forener natur og kultur og skaber mulighed for både rekreation og refleksion.

\section{Indtænkning i byens rum}

Bibliotekaren Kurt Sørensen skrev en kritisk anmeldelse af Rødovre Bibliotek i de yngre bibliotekarers tidsskrift Biblioteksdebat, som på flere måder skulle komme til at foregribe de kommende tiårs ændrede biblioteksbyggeri og biblioteksfilosofi. Han kritiserede den serielle funktionalitet og foregreb dermed det kommende opgør med modernismen. Planlæggerne havde ikke læst McLuhan og sat sig ind i deres samtids sensibilitet: "Der er ikke lagt overbevisende vægt på at publikum skal trives i disse indretninger, for i så fald ville strukturen været anderledes, mere upraktisk, labyrintisk, mosaikagtig ... Der er ingen tvivl om at storbibliotekets tid er forbi. Hvis det skal 
appellere til vor tids menneske, må det bestå af sammenbyggede butikker, centre hvor medier og mennesker mødes, hvor spændinger opstår og elektrisk musik skabes. Kinesiske æsker er fremtidens legetøj. Det lineært opbyggede og klart oversigtlige bibliotek tilhører en svunden epoke." (Sørensen, 1969/70, s. 11)

Arkitektonisk og byplanmæssigt førte periodens kritik af store forstadsområder med anonyme etageblokke og parcelhuskvarterer til forsøg på genskabelse af det traditionelle byrums kvaliteter. Modernismens slagord "Less is more" blev kritiseret og omskrevet med formuleringen "Less is a bore". Postmodernismen interesserede sig for symboler og kommunikation, og den europæiske nyrationalisme arbejdede for en arkitektonisk rekonstruktion af den klassiske by med dens bygningsmæssige arketyper og byrummets porte, gader, pladser og monumenter. De historiske forståelsesformer førte også til øget interesse for bevaring og genbrug af tidligere industribygninger.

Kulturpolitisk førte kritikken til, at der udvikledes en række nye forsamlingssteder i form af aktivitetshuse, beboerhuse og medborgerhuse, strækkende sig fra alternative steder som det københavnske Projekt Hus over græsrodsprægede beboerhuse til kommunale og officielt støttede medborgerhuse, kulturhuse og kulturelle rum som f.eks. Brandts Klædefabrik i Odense. Biblioteker udbyggedes fortsat som kulturhuse eller indgik som dele af kulturhuse eller sammenbygninger af flere kulturelle institutioner - med glidende overgange mellem de forskellige former. Disse huse lå ikke i grønne områder uden for byerne, men centralt og ofte i ældre kvarterer.

Som eksempler på biblioteker som dele af bycentre kan nævnes Aalborg fra 1980 og Holstebro fra 1981, tegnet med klar arkitektonisk profil af Hans Dall og Torben Lindhardtsen. Begge disse medborgerhuse og biblioteksbygninger søgte at forbinde offentlige institutioner med de omgivende byrum. De havde med deres massive rødstensmure et borgagtigt præg, men åbnede sig mod byrummet ved at føre gader og pladser ind i biblioteket. De svarede dermed til tidens interesse for at rekonstruere det traditionelle byrum i modsætning til modernismens funktionsbestemte byplaner. Biblioteksrummet var ikke kun funktionsbestemt, men også et trafikeret socialt rum. En hvid senmodernistisk udgave af samme biblio- tekstype udgøres af hovedbiblioteket i Gentofte fra 1985, tegnet af Henning Larsen. I den svenske by Sundsvall blev der i 1986 ved sammenbygningen af fire historiske magasinbygninger ved havnen skabt et spændende byrum med tilføjelsen af passager med glastag, som blev båret af slanke hvide metalsøjler. I gaderne mellem bygningerne er der både café, biblioteksudlån og avislæsepladser. Her tog kulturhuset udgangspunkt $i$ et byggeri fra industrialismens epoke.

I Aalborg brugte man navnet Medborgerhus om det sammenbyggede rådhus og bibliotek. Her realiseredes et helt system af indre gader og torve. Ligesom på Giambattista Nollis kort over Rom, hvor kirkers og klostres indre rum fik samme hvide markering som byens gader og pladser, blev biblioteket understreget som offentligt byrum og fik dermed en social og urban dimension ud over den funktionelle opstilling af samlingen. (Fig. 4 og 5) De små vinduer i medborgerhusets ydre og indre mure er indfattet af samme type betonelementer, således at facaderne fortsætter som husrækker ind i bygningen. Et lille trekantet torv leder hen til indgangen til biblioteket, og en indre gade fører ind til bibliotekets store udlånssal, der i sig selv er udformet som et stort bibliotekstorv. Omkring dette torv er bibliotekets øvrige aktiviteter grupperet.

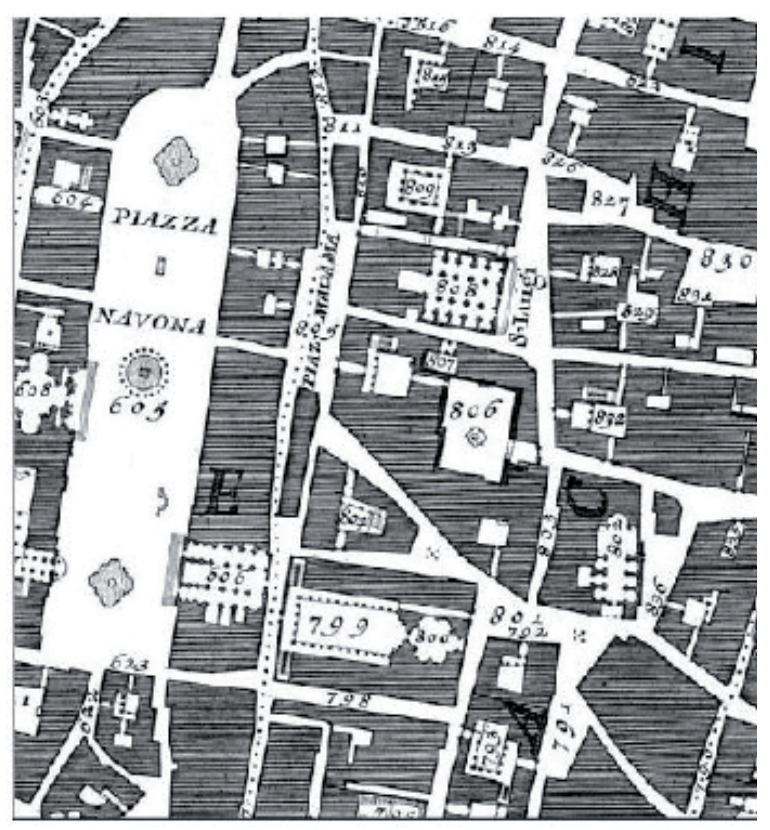

Figur 4. Nollis kort over Rom fra 1748 
Det sammenbyggede rådhus og bibliotek i Holstebro blev udformet efter tilsvarende principper. I det ydre bar bygningen præg af middelalderborg med massivt murværk, fremhævede fugninger og tårnagtige fremspring. I det indre var det rustikke inventar og den næsten armerede belysning gjort yderligere robust. Et indvendigt torv forbinder rådhuset og biblioteket. Den store trappe i den centrale sal giver associationer til en middelalderlig bjergby.

Til Dall og Lindhardtsens trio af firserbiblioteker hører også Ballerup Bibliotek fra 1982, der forbandt hovedgaden og stationen. Derved fik biblioteket en central placering og blev integreret $\mathrm{i}$ byens rum med nærhed til både station, busterminal og stationscenter. Hovedgadens flisebelægning med små sten er ført ind gennem biblioteksbygningen og understreger dermed passagen gennem biblioteket som offentlig forbindelsesgade. Den kunstneriske udsmykning er ligeledes med til at forbinde biblioteket med dets omgivelser. Niels Guttormsens Ballerup Byskulptur vokser op af fortovet med klatre- og legemuligheder og kaster imaginær skygge på bibliotekets mur.

Omkring årtusindskiftet er en stor del af de nyere biblioteker bygget ind i en større kulturel eller social sammenhæng. Samtidig er udviklingen gået i retning af større kulturhuse, som er i højere grad er præget af oplevelseskultur, sponsering og professionel organi- sering. I flere nye kulturhuse integreres biblioteker, biografer, teatre, koncerthuse og museer med forskelligartede rumlige udtryk og forbindelser til såvel massekulturens og som finkulturens offentlige rum. Dertil kommer årtusindskiftets kulturelle opbrud, den kommercielle og spektakulære begivenhedskultur og ambitionerne om opførelse af større eller mindre arkitektoniske ikoner.

Der flere således flere muligheder for at indtænke biblioteket i byens rum. (Dahlkild, 2007; Hvenegard Rasmussen, Jochumsen og Skot-Hansen, 2011, s. 113-133) En række nye amerikanske biblioteksbyggerier tager i høj grad udgangspunkt i en oplevelsesøkonomisk tænkning fra lærings- og oplevelsesbiblioteket i Cerritos syd for Los Angeles til store metropolbiblioteker som Chicago og Seattle, som markerer sig som "landmarks" i bylandskabet. (Mattern, 2007) De er præget af en spektakulær og eksperimenterede arkitektur, der markerer de amerikanske storbyer i deres indbyrdes profilering og konkurrence.

Kulturøen i Middelfart fra 2005 med bibliotek, biograf, café/restaurant og turistkontor kan ses i forlængelse af Bilbao-effekten, både beliggenhedsmæssigt og arkitektonisk. Med sin enestående beliggenhed ved havnefronten og ved sine skulpturelle former giver det associationer til Frank Gehrys Guggenheim

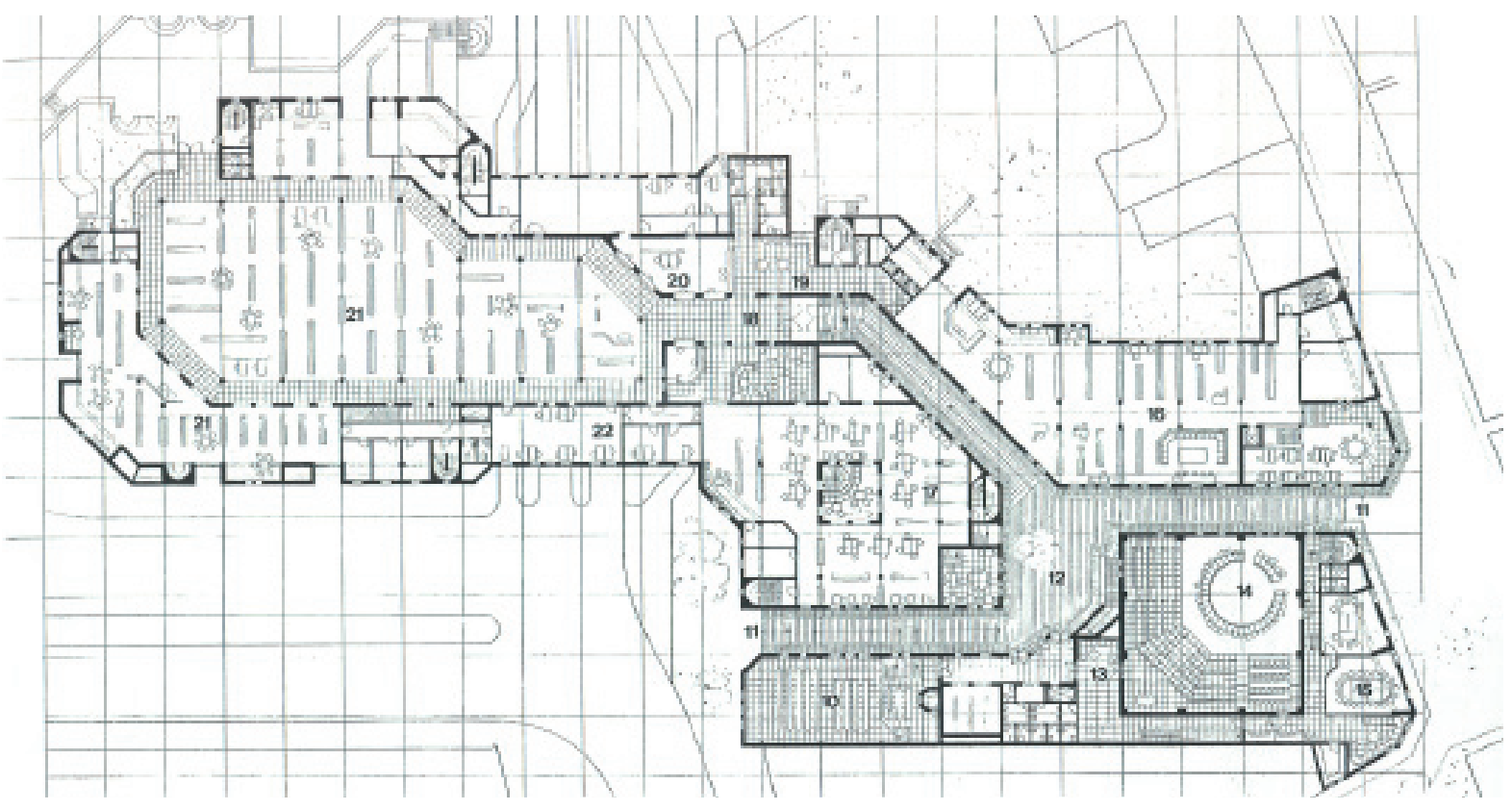

Figur 5. Aalborg Medborgerhus 
Museum i Bilbao. Tegnestuen Schmidt, Hammer og Lassen stod for udformningen af både ydre og indre og vedkendte sig inspiration fra både Alvar Aalto og Frank Gehry. I byfornyelsen af havnen indgik desuden et boligområde med punkthuse med altaner samt en ny lystbådehavn op til kulturhuset, der ligger som en $\varnothing$, der er omgivet af Lillebælt og spejlbassiner. I det ydre er bygningen præget af store skæve vinduespartier i hushøjde og svungne mure. I 2012 indviedes Kulturværftet i Helsingør med en tilsvarende central placering ved havnefronten. Også her integreres flere kulturelle institutioner med bevarelse og videreudvikling af industrihistoriske rammer og respekt for "stedets ånd". Transparente glasfacader forbinder kulturhuset med havnen og byen.

Det nye bibliotek i Hjørring fik i 2008 lokaler i butikscenteret Metropol og blev derfor ikke i det ydre nogen arkitektonisk ikon. Til gengæld fik biblioteket en original udformning i det indre, hvor "Det Røde Bånd" med sine svungne forløb brød afgørende med hidtidige lineære indretningsprincipper. Fortolket som byplan kunne indretningen minde om middelalderbyens krogede og uregelmæssige gadenet. Dette røde bånd forbinder som et garnnøgle bibliotekets temaområder, larme- og stillezoner og forskellige nicher, samtidig med at det selv ændrer karakter fra portal og reol til arbejdsbord og skråhylde med forskellige udstillinger. Undervejs bevæger båndet sig ud og ind mellem reolerne og passerer de ovale pladser. Næsten som en forenklet udgave af "Old World Reading Room" i Cerritos er der indrettet en læsesalon med øreklaplænestole i læder, mahogny-møbler og oliventræer. Visuelt associeres der til livsverden og hjemlig hygge. Designfirmaet Bosch og Fjord stod for bibliotekets indre.

Det Kongelige Bibliotek fik med udvidelsen og nybygningen i 1999 en markant placering ved den københavnske havnefront. Bygningen fik da også hurtigt status som arkitektonisk ikon med det medierette tilnavn "Den Sorte Diamant". Intentionerne om at gøre biblioteket til et åbent og demokratisk kulturhus understregedes yderligere gennem udnyttelsen af beliggenheden ved den befærdede havnepromenade. Mens den gamle biblioteksbygning vendte ryggen til havnen, især med Preben Hansens grå kontortilbygning fra tresserne, rykkede biblioteket nu helt frem til kajkanten og hældede ud over havneløbet. Hovedindgangen blev vendt ud mod havnepromenaden.
Arkitektonisk er der en spændende kontrast mellem diamantens ydre skarpe kanter og facade af blank sort granit og de indre rums lyse og næsten organiske karakter. Det gælder både foyeren med svungne hvide balkoner og læsesalene med interiører af lyst træ. Fra foyerens broer har man gennem glasfacaden i hele bygningens højde en enestående udsigt over havnen og lysreflekserne fra vandet. Fra udlånsbroen fører det rullende fortov "travelatoren" ned mod hovedindgangen. Udlånsbroen med loftsudsmykning af Per Kirkeby er et dynamisk rum, hvor bibliotekets trafik krydser byens trafik. Her integreres byens og bibliotekets rum. Fra broen kan man betragte strømmen af billygter på gaden nedenunder. Ligesom $\mathrm{i}$ tidens store internationale byggerier er der tale om spektakulære og transparente rum. Foyerens luftighed, størrelse og karakter af transitorisk rum peger også i retning af lufthavnsarkitekturens anonyme ankomst- og transithaller.

Netop placeringen og betydningen af foyeren som Diamantens arkitektoniske tomrum kan give anledning til en sammenligning af den gamle og den nye biblioteksbygning og deres centrale rum. I bogen Det Kongelige Bibliotek præsenterer Schmidt, Hammer og Lassen nybygningen i billedform med en kort indledning om deres intentioner. Her karakteriserer de selv foyerens karakter: "Som en kontrast til Diamantens ydre ses atriet som bygningens organiske indre. De bølgende skrå vægge refererer til det menneskelige, til kroppen og sjælens indre verden." (Schmidt, Hammer \& Lassen, 1999, s. 13) Teksten fortsætter med sætningen: "Bygningens foyerareal er bibliotekets nye centrale rum." (Schmidt, Hammer \& Lassen, 1999, s. 13) Man kan sammenligne med en tilsvarende sætning i Kell Elgstrøms karakteristik af den gamle biblioteksbygning, hvor det er læsesalen, der defineres som det vigtigste rum: "Læsesalen er uden sammenligning bibliotekets mest imposante rum." (Elgstrøm, 1993, s. 44) Interessant er forskydningen fra læsesalen til foyeren som bibliotekets centrale rum. En anden tydelig kontrast er forskellen mellem diamantens glatte sorte facade og den gamle bygnings mange symbolbærende detaljer.

Mens Kulturøen i Middelfart og Den Sorte Diamant er spektakulære ikoner, der svarer til forestillinger om Bilbao-effekten, er andre byggerier tænkt i en mere lokal og social sammenhæng, hvor de på forskellig måde kan medvirke til at styrke den sociale sammenhængskraft. 
Udbygningen af Kvartershuset i Holmbladsgadekvarteret var således en del af et kvartersløft af et tidligere fabriksområde på det nordlige Amager, der var præget af nedslidning og sociale problemer. Biblioteket flyttede i 2001 fra en beliggenhed i Amager Centret til en tidligere pakhusbygning fra 1880'erne, hvor det indgik i et netværk sammen med en række lokalt forankrede institutioner og organisationer. Husets aktiviteter var fra starten præget af stort engagement i områdets udvikling. Hele komplekset er tegnet af Dorte Mandrups Tegnestue.

Husets tilbyggede mødesal på de mange stammer af skæve betonsøjler er blevet sammenlignet med en hytte i træerne. Mødesalen med de fire glasvægge, hvor man kan se både ind og ud, er ud over at være en del af det arkitektoniske formsprog et fint udtryk for forbindelsen mellem kvartershusets aktiviteter og omverdenen. Rammekonstruktionen i lyst træ giver samtidig mindelser om en reol. En gangbro med egen indgang gør det muligt at bruge mødesalen uafhængigt af bibliotekets åbningstider.

I 2011 indviedes i Københavns robuste nordvestkvarter et nyt Bibliotek og Kulturhus med forskudte gyldne kuber, som associerer til en stak bøger. Det nye kulturhus indeholder både bibliotek, borgerservice, café, lokaludvalg, værksteder, lokal-TV/ lokalradio og medborgercenter. Det er tegnet i et samarbejde mellem arkitekt- og byplantegnestuerne Cobe+Transform.

Foyeren åbner sig som en indre gade mellem den gamle og den nye bygning. Her fornemmes intentionerne bag cafeen som "tredje sted". Den gyldne biblioteksbygning består af 4 bokse - eller 4 bøger med hver sit indhold - lagt oven på hinanden. Hvert rum har sin afgrænsning og karakter. En særlig kube med betjening, udstillinger, nye bøger og reservationer skyder sig frem forneden. Længere inde ligger børnebiblioteket Grotten, møbleret som et legelandskab med små kubiske kasser i grønne, gule og hvide farver, som både kan bruges til klatring, som siddepladser, som reoler og til udstilling. På første sal ligger ungdomsafdelingen, hvor man træder ind i en sølvfarvet Aladdins hule med edderkoppelignende lysekroner. Afdelingen for skønlitteratur er bygningens hyggeligste rum med paneler og reoler af lyst fyrretræ og magelige læderstole i kontrast til nogle af de mere industrielle rum.
Kvartershuset i Holmbladsgade og Biblioteket og Kulturhuset på Rentemestervej kan ses som eksempler på bibliotekets betydning i forbindelse med kvarterløft og lokal udvikling. De kan sammenlignes med forskellige initiativer i London, både i form af de såkaldte "idea stores" med et helt nyt biblioteksbegreb og biblioteket i Peckham som et stykke avantgarde-arkitektur i et nedslidt kvarter i det sydlige London. De viser interessen for bibliotekernes rolle som "placemaker" i byudviklingen, både som arkitektoniske ikoner, som økonomiske igangsættere og som sociale, uddannelsesmæssige og kulturelle aktører i forbindelse med byfornyelse af problemområder.

\section{Perspektiver}

De valgte eksempler viser de sociale, funktionelle og æstetiske sammenhænge mellem bibliotekernes indre og ydre rum. Biblioteksrummet har udviklet sig fra et rum omkring en samling over ambitionerne om en selvstændig bygning med central placering på hovedgaden til modernismens rationelle og serielle modulbiblioteker og videre til årtusindskiftets indtænkning i byudviklingen som kulturelt, socialt og økonomisk incitament, iøjnefaldende landmark og "library without walls". Samtidig afspejler eksemplerne forskellige perioders biblioteksfilosofi, identiteter og kulturpolitik med stadig nye aktiviteter, som kommer til udtryk i bygningernes fremtræden, udformning, indretning og betydning som offentlige rum. Historisk har udviklingen for folkebibliotekernes vedkommende bevæget sig fra de lokale bogsamlingers og læsestuers livsverden over mellemkrigstidens og tressernes ambitioner om professionaliserede og rationelt organiserede institutioner til årtusindskiftets forsøg på at undgå institutionspræg og rekonstruere sammenhængen med livsverdenen. Den elektroniske udvikling har samtidig skabt interesse for at gentænke det fysiske biblioteksrums muligheder med perspektiver i retning af bibliotekets identitet som socialt frirum med lokal forankring og dermed som et "tredje sted", der svarer til "stedets ånd".

Eksempler på indtænkning i byrummet er Medborgerhuset i Aalborg eller Biblioteket på Rentemestervej i Københavns nordvestkvarter, hvor indre gader og pladser forbinder biblioteksrummet med omgivelserne. Denne opfattelse svarer til byudviklingen, hvor lineært planlagte byer afløses af mere komplekse strukturer. Ligesom en tur i byen kan det fysiske 
biblioteksrum give mulighed for det uventede fund eller det overraskende møde, som ikke kan erstattes af en søgning på nettet.

Denne indtænkning gælder basale beliggenhedsmæssige og trafikale forhold, men kan også anvendes på planlægningen af bibliotekerne som indre byrum. Ligesom torvet er det traditionelle mødested i byen, kan bibliotekstorvet være et indre mødested med de nyeste medietilbud og skiftende aktuelle udstillinger som attraktioner. Her kan også bibliotekets forskellige selvbetjeningsfunktioner placeres. Torvet er kendetegnet af højt forandringsberedskab og udskiftelighed. Brugen som diskussions- og mødested svarer til byens pladser udenfor.

Fra torvet kan man sig bevæge sig videre gennem bibliotekets indre gader og passager til de forskellige afdelinger eller "kvarterer". I den indre byplan kan indtænkes mange forskellige former for ophold, oplevelser og serendipitet. Kvartererne kan gennem deres indretning signalere de emner, de indeholder, ved hjælp af forskellig møblering eller karakteristiske ikoner/genstande. Placering og formidling af materialer og tilbud vil afhænge af brugergruppen og dermed kvarterets sociale karakter. Andelen af bøger og andre materialer og tætheden af møblering og reoler kan variere. Som kvarter kan en del af biblioteket have karakter af et Fiolstræde, hvor samlingen rummer kulturarv og klassisk litteratur, der er uopdrivelig på et stadigt hastigere cirkulerende bogmarked og ikke nødvendigvis er digitaliseret. Serendipitet og fordybelse er og har altid været centrale aspekter af bibliotekets identitet. Åbningen af bibliotekets magasiner fuldender åbningen af biblioteksrummet tilbage fra indførelsen af "åbne hylder" i starten af det 20. århundrede.

Dele af bibliotekerne kan have karakter af forandringszoner med skiftende funktioner og indretningsmuligheder, mens andre kan være mere stabile og understrege bibliotekernes betydning for kulturarv og oplysning. Der kan eksperimenteres med varierede åbningstider i dele af biblioteksrummet, ligesom byens forskellige kvarterer lever på forskellige tider af døgnet. Variationen kan komme til udtryk gennem forskellig indretning af forskellige rum, strækkende sig fra bibliotekets mest åbne og torveagtige dele til eftertragtede stillezoner og fordybelsesrum uden forstyrrelser, hvor der er mulighed for læring, koncentration og refleksion. Forskellige materialer, møb- lering og farver kan markere og adskille forskellige rum. Der er mulighed for at etablere rum i rummet, f.eks. til særlige opgaver som borgerservice eller et lokalhistorisk arkiv.

Der er mange fine eksempler på grønne områder som gårdhaver og frirum i og omkring biblioteket. Den franske biblioteksteoretiker Gabriel Naudé anbefalede at anbringe biblioteket sammen med en smuk have, som kunne give læseren en behagelig udsigt. Som parken i byen kan grønne rum som haver eller væksthuse være naturlige dele af bibliotekets identitet.

\section{Referencer}

Bæk Pedersen, P (2005). Arkitektur og plan i den danske velfcerdsby 1950-1990. Århus: Arkitektskolens Forlag.

Cullen, G (1961). The Concise Townscape. London: The Architectural Press.

Dahlkild, N (2007). Biblioteket som byrum. Danmarks Biblioteker, 2007:8, 32-34.

Dahlkild, N (2011). Biblioteket i tid og rum. Arkitektur, indretning og formidling. København: Danmarks Biblioteksforening.

Juul, H (Ed.) (2009). Det kendte i det fremmede. Byens rum 2. København: Fonden til udgivelse af Arkitekturtidsskrift B.

Drehn-Knudsen, E (1967). Folkebiblioteker i Danmark. København: Bibliotekstilsynet.

Døssing, T (1924). Folkebibliotekerne før og nu. København: Steen Hasselbalchs Forlag.

Elgstrøm, K (1993). Det Kongelige Bibliotek - et hus på Slotsholmen. København: Det kongelige Bibliotek.

Estvad Petersen, S (2000). Ideernes vandring. København: Gyldendal.

Fröberg, VH (1998). Tystnaden och ljuset. Om bibliotekens arkitektur. Stockholm: Carlssons. 
Gehl, J (1971). Livet mellem husene. København: Arkitektens Forlag.

Gehl, J \& Gemzøe, L (2000). Nye byrum. København: Arkitektens Forlag.

Greenhalgh, L, Landry, C \& Worpole, K (1995). Libraries in a world of cultural change. London: UCL Press.

Hansen, RL (1938). Det nye Bibliotek i Thisted. Bogens verden, 1938, 165-172.

Hvenegard Rasmussen, C, Jochumsen, H \& SkotHansen, D (2011). Biblioteket i byudviklingen. Oplevelse, kreativitet og innovation. København: Danmarks Biblioteksforening.

Jencks, C (2005). The Iconic Building. The Power of Enigma. London: Frances Lincoln.

Linn, B (2002). Biblioteket och staden I: Gram, M (Ed.). Bibliotek och arkitektur. Stockholm: Arkitekturmuseet. With an English summary.

Lynch, K (1960). The Image of the City. Massachusetts: The M.I.T. Press.

Shannon, M (2007). The New Downtown Library. Designing with Communities. Minnesota: University of Minnesota Press.

Mitchell, WJ (1999). e-topia. Cambridge \& London: The MIT Press.

Naudé, G (1627/1970). Vejledning i biblioteksarbejde. Oversat og annoteret af RL Hansen. København: Gad.
Norberg-Schulz, C (1980). Genius Loci. Towards a Phenomenology of Architecture. London: Academy Editions.

Oldenburg, R (1989). The Great Good Place. Cafés, Coffee Shops, Bookstores, Bars, Hair Salons and other Hangouts at the Heart of a Community. New York: Marlowe \& Company.

Oldenburg, R (Ed.) (2001). Celebrating the Third Place. New York: Marlowe \& Company.

Pevsner, N (1976). A History of Building Types. London: Thames and Hudson.

Plovgaard, S (1957). Hørsholm Bibliotek. Bogens Verden, 1957, 81-87.

Plovgaard, S (1967). Folkebiblioteksbygningen. Normer og typeplaner for bibliotekslokaler i områder med 5.000 til 25.000 indbyggere. København: Bibliotekscentralen.

Schmidt, Hammer og Lassen (1999). Det Kongelige Bibliotek. Arkitektur i billeder. København: Gyldendal.

Sørensen, K (1969/70). Prestigebiblioteker. Biblioteksdebat, 1969/70:1, 10-11.

Thomas, NP (1996). Reading Libraries. An interpretative study of discursive practices in library architecture and the interactional construction of personal identity. Ann Arbor: State University of New Jersey. 